\title{
Importance of biogenic precursors to the budget of organic nitrates: observations of multifunctional organic nitrates by CIMS and TD-LIF during BEARPEX 2009
}

\author{
M. R. Beaver ${ }^{1, *}$, J. M. St. Clair ${ }^{1}$, F. Paulot ${ }^{1}$, K. M. Spencer ${ }^{1}$, J. D. Crounse ${ }^{1}$, B. W. LaFranchi ${ }^{2,{ }^{* *}}$, K. E. Min ${ }^{2}$, \\ S. E. Pusede ${ }^{2}$, P. J. Wooldridge ${ }^{2}$, G. W. Schade ${ }^{3}$, C. Park ${ }^{3, * * *}$, R. C. Cohen ${ }^{2}$, and P. O. Wennberg ${ }^{1}$ \\ ${ }^{1}$ California Institute of Technology, Pasadena, CA, USA \\ ${ }^{2}$ University of California, Berkeley, CA, USA \\ ${ }^{3}$ Texas A\&M University, College Station, TX, USA \\ * now at: National Exposure Research Laboratory, Environmental Protection Agency, Research Triangle Park, NC, USA \\ ** now at: Center for Accelerator Mass Spectrometry, Lawrence Livermore National Laboratory, Livermore, CA, USA \\ *** now at: University of California, Los Angeles, CA, USA
}

Correspondence to: M. R. Beaver (beaver.melinda@epa.gov)

Received: 11 November 2011 - Published in Atmos. Chem. Phys. Discuss.: 4 January 2012

Revised: 23 May 2012 - Accepted: 6 June 2012 - Published: 3 July 2012

\begin{abstract}
Alkyl and multifunctional organic nitrates, molecules of the chemical form $\mathrm{RONO}_{2}$, are products of chain terminating reactions in the tropospheric $\mathrm{HO}_{\mathrm{x}}$ and $\mathrm{NO}_{\mathrm{x}}$ catalytic cycles and thereby impact ozone formation locally. Many of the molecules in the class have lifetimes that are long enough that they can be transported over large distances. If the $\mathrm{RONO}_{2}$ then decompose to deliver $\mathrm{NO}_{\mathrm{x}}$ to remote regions they affect ozone production rates in locations distant from the original $\mathrm{NO}_{\mathrm{x}}$ source. While measurements of total $\mathrm{RONO}_{2}(\Sigma \mathrm{ANs})$ and small straight chain alkyl nitrates are routine, measurements of the specific multifunctional $\mathrm{RONO}_{2}$ molecules that are believed to dominate the total have rarely been reported and never reported in coincidence with ambient $\Sigma$ ANs measurements. Here we describe observations obtained during the BEARPEX 2009 experiment including $\Sigma$ ANs and a suite of multifunctional nitrates including isoprene derived hydroxynitrates, oxidation products of those nitrates, 2-methyl-3-buten-2-ol (MBO) derived hydroxynitrates, and monoterpene nitrates. At the BEARPEX field site, the sum of the individual biogenically derived nitrates account for two-thirds of the $\Sigma$ ANs, confirming predictions of the importance of biogenic nitrates to the $\mathrm{NO}_{\mathrm{y}}$ budget. Isoprene derived nitrates, transported to the site, are a much larger fraction of the $\Sigma$ ANs at the site than the nitrates derived from the locally emitted MBO. Evidence for
\end{abstract}

additional nitrates, possibly from nocturnal chemistry of isoprene and $\alpha$-pinene, is presented.

\section{Introduction}

Nitrogen oxides affect rates of ozone production throughout the troposphere. They are emitted from soils, lightning, and natural and anthropogenic combustion, primarily as $\mathrm{NO}$ but also as $\mathrm{NO}_{2}$ and HONO. In the troposphere, these compounds are oxidized to a mix of compounds including peroxynitrates $\left(\mathrm{RO}_{2} \mathrm{NO}_{2}\right)$, alkyl and multifunctional nitrates $\left(\mathrm{RONO}_{2}\right)$, and $\mathrm{HNO}_{3}$. The individual components of this $\mathrm{NO}_{\mathrm{y}}$ family are transported throughout the troposphere, where they can deposit, enriching soil $\mathrm{N}$ content, or undergo photochemistry releasing $\mathrm{NO}_{\mathrm{y}}$ and contributing to enhanced production of ozone far from their source.

Alkyl nitrates are formed from the reaction of organic peroxy radicals $\left(\mathrm{RO}_{2}\right)$ with $\mathrm{NO}$. The major channel of this reaction forms $\mathrm{NO}_{2}$, Reaction (R1), the photolysis of which leads to ozone formation. A minor reaction pathway of $\mathrm{RO}_{2}$ radicals with $\mathrm{NO}$ forms organic nitrates, $\mathrm{RONO}_{2}$, Reaction (R2).

$\mathrm{RO}_{2}+\mathrm{NO} \rightarrow \mathrm{RO}+\mathrm{NO}_{2}$

$\mathrm{RO}_{2}+\mathrm{NO} \rightarrow \mathrm{RONO}_{2}$ 
The yield $(\alpha=\mathrm{R} 2 /(\mathrm{R} 1+\mathrm{R} 2))$ of this minor, radical terminating pathway depends on the carbon chain length and structure of the VOC oxidized, and can range from a fraction of a percent for methane to $35 \%$ for large molecules (Atkinson and Arey, 2003b). Nocturnal nitrate radical chemistry also forms organic nitrates often with large yields up to $80 \%$ (Hallquist et al., 1999; Fry et al., 2009). The lifetime and yield of these organic nitrate species with respect to deposition and further oxidation, along with the fate of the products from oxidation, control the effect of $\mathrm{RONO}_{2}$ on global $\mathrm{NO}_{\mathrm{x}}$ redistribution and local ozone formation.

The importance of alkyl nitrates to both global and regional ozone production has been recognized. Different chemical representations of alkyl nitrates in models, specifically isoprene nitrates, have been found to explain differences in global simulations of tropospheric ozone (Ito et al., 2007; Wu et al., 2007). Depending on the chemical mechanism used, i.e. the formation yield, lifetime, and $\mathrm{NO}_{\mathrm{x}}$ recycling of these nitrates, ozone production behavior can vary widely (Paulot et al., 2012). Treatment of alkyl nitrates as permanent sinks for $\mathrm{NO}_{\mathrm{x}}$ can disguise the sensitivity of ozone production to biogenic emissions such as isoprene, and causes much of the simulated global atmosphere to be VOC saturated (Wu et al., 2007). Farmer et al. (2011), using Mexico City as a case study, have recently demonstrated alkyl nitrate formation can complicate efforts to engineer improved air quality due to non-linear interactions of $\mathrm{VOC}$ and $\mathrm{NO}_{\mathrm{x}}$ emissions.

Isoprene nitrates are a central focus of studies investigating ozone production since globally, isoprene (2-methyl-1,3butadiene) emissions dwarf those of other biogenic volatile organic compounds. $440-660 \mathrm{Tg} \mathrm{C} \mathrm{yr}^{-1}$ are emitted to the atmosphere as isoprene (Guenther et al., 2006). However, regionally and locally, other VOCs such as monoterpenes and oxygenated VOCs can dominate reactivity. Isoprene has a lifetime of approximately $3 \mathrm{~h}$ at typical atmospheric hydroxyl radical concentrations of $1 \times 10^{6}$ molecules $\mathrm{cm}^{-3}$ (Atkinson et al., 2006). However, organic nitrates function to increase the spatial scale where relatively short-lived VOCs can impact $\mathrm{NO}_{\mathrm{x}}$ concentrations and ozone formation. The formation of organic nitrates from biogenic VOCs couples anthropogenic $\mathrm{NO}_{\mathrm{x}}$ emissions with naturally occuring VOC emissions.

The branching ratio between pathway (R2) and (R1) for isoprene has been studied extensively, and a range of yields for Reaction (R2) between 4.4 and $15 \%$ have been reported (Tuazon and Atkinson, 1990; Chen et al., 1998; Chuong and Stevens, 2002; Sprengnether et al., 2002; Patchen et al., 2007; Lockwood et al., 2010; Paulot et al., 2009a). This yield has also been found to be temperature and pressure dependent (Crounse et al., 2011; Carter and Atkinson, 1989). Ambient observations over the continental US during ICARTT/INTEX-NA of alkyl nitrates attributed to isoprene are consistent with a similar range of Reaction (R2) yield (4.4 to $12 \%$ ), depending on the subsequent fate of the ni- trates (Perring et al., 2009a). Another analysis of this dataset using the MOZART chemical transport model suggested that a nitrate yield from isoprene of $4 \%$ was the most consistent with the sum of ANs to ozone ratios (Horowitz et al., 2007). A deposition rate of the isoprene nitrates equal to nitric acid deposition was also necessary to explain boundary layer concentration observations. Horowitz et al. (2007) used, however, a rate for the reaction of $\mathrm{HO}_{2}$ with isoprene peroxy radicals a factor of two lower than now recommended by MCM (Saunders et al., 2003) thus substantially overestimating the fraction of isoprene peroxy radicals reacting with NO.

Predictions of global ozone are very sensitive to the yield for isoprene nitrate formation. Wu et al. (2007), using the GEOS-Chem model, found a $10 \%$ decrease in global ozone production rates by increasing the yield for isoprene nitrate formation from $4.4 \%$ (Chen et al., 1998) to $12 \%$ (Sprengnether et al., 2002). Paulot et al. (2012) similarly illustrated the remarkable sensitivity of tropical ozone to this yield.

The fate of isoprene hydroxynitrates, ISOPN, has been the subject of recent research. The lifetime of ISOPN, with respect to $\mathrm{OH}$ and ozone is relatively short due to the presence of a double bond. For example, the E-1,4-ISOPN isomer is estimated to have a lifetime of $2.9 \mathrm{~h}$ (Paulot et al., 2009a) and 5.33 h (Lockwood et al., 2010) at $\mathrm{OH}=1 \times$ $10^{6}$ molecules $\mathrm{cm}^{-3}$ and $40 \mathrm{ppb} \mathrm{O}_{3}$, respectively. Lifetimes vary greatly amongst the possible ISOPN isomers, for the same oxidant conditions, the 1,2-IN has a lifetime of $28 \mathrm{~h}$ and $2.7 \mathrm{~h}$ with respect to $\mathrm{OH}$ and $\mathrm{O}_{3}$. The oxidation of isoprene hydroxynitrates can either release $\mathrm{NO}_{\mathrm{x}}$ as $\mathrm{NO}_{2}$ or retain the organic nitrate functionality. Paulot et al. (2009a) have shown that approximately $50 \pm 15 \%$ (weighted average of the 8 isomers) of the isoprene nitrates recycle $\mathrm{NO}_{\mathrm{x}}$ upon further photooxidation by OH. Horowitz et al. (2007) found $\mathrm{NO}_{\mathrm{x}}$ recycling of $40 \%$ agreed with ambient observations, using a low yield of nitrates, and a fast deposition (similar to nitric acid). A fraction of isoprene hydroxynitrates retain the nitrate functionality upon oxidation by forming methyl vinyl ketone nitrate (MVKN), methacrolein nitrate (MACRN), propanone nitrate (PROPNN), and ethanal nitrate (ETHLN) (Paulot et al., 2009a). $\mathrm{NO}_{\mathrm{x}}$ recycling levels from the ozonolysis of isoprene hydroxynitrates are unclear (Lockwood et al., 2010).

Organic nitrate yields from biogenic VOCs other than isoprene have not been studied as extensively. Alvarado et al. (1999) found a yield of $5.2 \%$ for the dihydroxynitrate from MBO, MBON. Chan et al. (2009) report a higher yield of $\sim 10 \%( \pm 4 \%)$. MBON contains no double bond, and the lifetime with respect to $\mathrm{OH}$, assuming an ambient $\mathrm{OH}$ concentration of $1 \times 10^{6}$ molecules $\mathrm{cm}^{-3}$ is approximately 6 days (Saunders et al., 2003). Yields and lifetimes of organic nitrates from monoterpenes such as $\alpha$-pinene have also been reported. Currently, these range from $1-18 \%$ yield (Aschmann et al., 2002; Noziere et al., 1999). 
Reactions of nitrate radical with biogenic VOCs, including isoprene (Rollins et al., 2009; Perring et al., 2009b), and $\alpha$ pinene and $\beta$-pinene (Hallquist et al., 1999; Fry et al., 2009) are also sources of organic nitrate species. From an analysis of ICARTT field data from the Eastern US, Horowitz et al. (2007) found half of the isoprene nitrates were formed from isoprene $+\mathrm{NO}_{3}$ chemistry, despite a small fraction $(\sim 6 \%)$ of isoprene oxidized by $\mathrm{NO}_{3}$ chemistry. Brown et al. (2009) using ambient data from flights over the Northeast US, found that $73 \%$ of the loss of the nitrate radical was due to the oxidation of isoprene. Using the same dataset, they inferred $2-9 \%$ of total reactive nitrogen was composed of organic nitrates formed from this reaction, using a nitrate yield of $80 \%$ for the isoprene $+\mathrm{NO}_{3}$ reaction (Barnes et al., 1990).

Ambient measurements of specific individual $\mathrm{RONO}_{2}$ have, with few exceptions (Fischer et al., 2000; Grossenbacher et al., 2001, 2004), been limited to simple alkyl nitrates. As a result of the development of thermal dissociation laser induced fluorescence (TD-LIF) by Day et al. (2002), measurement of total alkyl-nitrates ( $\Sigma$ ANs) as a class has become routine. In this study, we use chemical ionization mass spectrometry (CIMS) measurements interpreted as organic nitrates in combination with the sum of total alkyl nitrates ( $\Sigma$ ANs) measurements from TD-LIF to determine the absolute concentrations and speciation of organic nitrates at an urban-impacted, forested measurement site. The dataset was collected as part of the Biosphere Effects on AeRosol and Photochemistry EXperiment, BEARPEX 2009. The measurement site is locally surrounded by dominantly non-isoprene emitting pine species; however, the site receives advected isoprene and isoprene oxidation products from the oak-rich region between the measurement site and Sacramento (Dreyfus et al., 2002). One modeling study has predicted organic nitrates from isoprene and other biogenic VOCs dominate the alkyl nitrate budget at the site (Perez et al., 2009). We report measurements of first and second generation organic nitrates from isoprene and an MBO derived nitrate. We also propose chemical structures for other nitrogen-containing compounds measured at the site. Overall, these measurements confirm that the alkyl nitrate budget at this rural site is dominated by nitrates derived from biogenic VOC precursors and that $\mathrm{RONO}_{2}$ is an important fraction of $\mathrm{NO}_{\mathrm{y}}$.

\section{Experimental}

\subsection{Site description}

The measurements presented here were obtained during the Biosphere Effects on AeRosol and Photochemistry EXperiment, BEARPEX 2009. One science goal of the collaborative research campaign was to understand forest-atmosphere interactions and how the urban plume of Sacramento influences these interactions. The measurement site is located in the Western foothills of the Sierra Nevada at $38.90^{\circ} \mathrm{N}$, $120.63^{\circ} \mathrm{W}$, at $1315 \mathrm{~m}$ elevation, approximately $75 \mathrm{~km}$ northeast of Sacramento (Goldstein et al., 2000). The immediate vegetation is a Ponderosa pine forest plantation managed by Sierra Pacific Industries. Average canopy height in 2009 was $8.7 \mathrm{~m}$. The dominant summertime meteorology affecting the site is a thermally driven upslope flow that brings air from California's Central Valley into the Sierra Nevada foothills; at night, this flow reverses, and returns to the Valley (Dillon et al., 2002). The major anthropogenic inputs to the plume are from vehicular traffic in Sacramento and its surrounding suburbs. Between Sacramento and the measurement site, there is a $30 \mathrm{~km}$ wide oak tree belt which contributes significant emissions of isoprene to the urban plume (Goldstein et al., 2000; Dreyfus et al., 2002). The measurement site contained two scaffolding towers used to deploy a variety of chemical and meteorological instrumentation along with sampling inlets. The Caltech CIMS instrumentation suite was located at the top of the North scaffolding tower, with an inlet height of $17.8 \mathrm{~m}$, approximately $9 \mathrm{~m}$ above the top of the forest canopy.

\subsection{Instrumentation}

Organic nitrates were quantified using the Caltech triple quadrupole tandem chemical ionization mass spectrometer. This instrument utilizes $\mathrm{CF}_{3} \mathrm{O}^{-}$as the reagent ion, and is described in detail elsewhere (St. Clair et al., 2010). In general, this ionization chemistry has been found to be selective for acidic species, peroxides, and multifunctional (hydroxy- and nitrooxy-) molecules (Crounse et al., 2006). This instrument was also used to measure oxidation products of isoprene during the summer NASA ARCTAS campaign in 2008 (Paulot et al., 2009b). Briefly, ambient air was pulled through the inlet at $30 \mathrm{~m} \mathrm{~s}^{-1}$, then the center of this flow was sampled into the single quadrupole CIMS instrument's reduced pressure $(\sim 35 \mathrm{hPa})$ flow tube. The bypass flow was then sampled by the triple quadrupole CIMS, similar to the sampling arrangement described by St. Clair et al. (2010). The ambient flow was diluted to a 1:7 ratio with dry $\mathrm{N}_{2}$ to lower the water vapor concentration in the flow tube.

The triple quadrupole CIMS instrument was operated alternately in two mass filtration modes: single mass spec (sMS) and tandem (MSMS) modes. When operating in sMS mode, the first quadrupole selected the $m / z$ ratio to be observed, then the remaining two quadrupoles were used as ion guides. The data presented here were measured in sMS mode, since no known mass interferences exist. Each $m / z$ ratio was observed for $0.5 \mathrm{~s}$ once approximately every 4-6 min. The remainder of the duty cycle was spent in MSMS mode. Instrumental background signals were measured at each mass, once approximately every $1.6 \mathrm{~h}$, by scrubbing the analytes from ambient air using a two-stage filter containing palladium coated alumina pellets and sodium bicarbonate treated nylon wool (Spencer et al., 2011). The background 
signals were measured at approximately the same water vapor concentration as the ambient data. To determine ambient concentrations, an interpolation between these background signals was subtracted from the ambient signals. Also, starting at julian day 199, approximately every $1.6 \mathrm{~h}$, ambient scans and background scans up to $\mathrm{m} / \mathrm{z} 325$ were conducted. Since this technique provides no prior separation step, no isomeric information is determined, and measurements are reported as the sum of the possible isomers (geometric or structural).

The $\mathrm{CF}_{3} \mathrm{O}^{-}$CIMS technique induces minimal fragmentation, therefore nitrates are observed at the $m / z$ of the parent molecule $+85\left(\mathrm{CF}_{3} \mathrm{O}^{-}\right)$. The lack of fragmentation aids in the determination of the molecular weight of the species, since authentic standards of the organic nitrates presented here are unavailable. We use theoretically derived sensitivities to determine concentrations. Relative sensitivities of the organic nitrates to nitric acid were assumed to be equal to the relative rates of the molecule's collision with $\mathrm{CF}_{3} \mathrm{O}^{-}$. The collision rates with $\mathrm{CF}_{3} \mathrm{O}^{-}$were calculated according to $\mathrm{Su}$ and Chesnavich (1982) and Garden et al. (2009). Polarizibilites and dipole moment calculations were conducted using quantum chemical computations using the B3LYP/631G(d) level of theory (Garden et al., 2009). Comparisons of theoretical sensitivity calculations to measured sensitivities has been shown to compare well (Paulot et al., 2009b). For some analytes, the sensitivity of this technique is known to depend on water (Crounse et al., 2006; St. Clair et al., 2010). To determine the sensitivity of the nitrate clusters with the $\mathrm{CF}_{3} \mathrm{O}^{-}$reagent ion, environmental chamber experiments were performed to produce the isoprene hydroxynitrates, similar to the conditions outlined in Paulot et al. (2009a). The CIMS sampled from the sample chamber and water vapor was varied across the relevant range for this campaign, and sensitivity remained constant. Therefore, no water dependent sensitivity was applied to the ambient data. Nitrate formation yields determined from these experiments were in agreement with Paulot et al. (2009a). The estimated uncertainty for the CIMS concentrations presented here is $\pm 40 \%$, dominated by the uncertainty in the theoretical predictions of sensitivity.

The signal at any $m / z$ can contain an interference from the naturally occurring ${ }^{13} \mathrm{C}$ isotope signal produced from the species at the $m / z-1 \mathrm{amu}$. The higher the number of carbon atoms in a molecule, the larger the contribution to the $\mathrm{m} / \mathrm{z}$ signal from the ${ }^{13} \mathrm{C}$ isotope. It is possible to correct for this interference if a molecular formula for the species producing the $m / z-1$ ion is known or assumed. Specifically, the interference contribution has been removed by calculating $1.1 \%$ * the number of carbons in the molecule that produces the $m / z-1$ ion * the signal at $m / z-1$, and subtracting this signal from the $m / z$ signal. We evaluated this correction method using the large ambient signal at $\mathrm{m} / \mathrm{z} 159$ due to hydroxyacetone. The ratio of the signal at 160 to 159 was 0.047 , consistent with the expectation from the $m / z+1$ isotopologue of hydroxyacetone cluster with the reagent ion. For the nitrates presented here, this correction was applied only to the PROPNN signal, observed at $m / z$ 204, due to the large ambient signal observed at $m / z 203$ (known to be due to isoprene hydroxyhydroperoxide + isoprene dihydroxyepoxide) (Paulot et al., 2009a). For the other even masses, the isotopologues of the $m / z-1$ signals are too small to contribute to the nitrogen signals.

The sum of total alkyl nitrates, $\Sigma$ ANs, measurement was made by the University of California Berkeley using a thermal dissociation laser induced fluorescence, TD-LIF, instrument similar to that of Day et al. (2002). Briefly, the instrument measures $\mathrm{NO}_{2}$ by LIF, and thermally dissociates most other constituents of $\mathrm{NO}_{\mathrm{y}}$ into $\mathrm{NO}_{2}$ then measures their contribution by the difference between channels. Specifically, in this instrument $\Sigma$ ANs characteristically dissociate into $\mathrm{NO}_{2}$ and a companion radical completely at temperatures greater than or equal to $380^{\circ} \mathrm{C}$. The difference in the $\mathrm{NO}_{2}$ signal between ambient air passing through the $380^{\circ}$ oven ( $\Sigma$ ANs $+\Sigma$ PNs $\left.+\mathrm{NO}_{2}\right)$ and the $200^{\circ}$ oven $\left(\Sigma \mathrm{PNs}+\mathrm{NO}_{2}\right)$ is attributed to $\Sigma$ ANs. Measurements in the lab and under field conditions show that $\mathrm{HNO}_{3}$ is not detected in the $\Sigma \mathrm{AN}$ channel. The instrument is routinely calibrated using an $\mathrm{NO}_{2}$ gas standard $\left(4.9 \pm 0.2 \mathrm{ppm} \mathrm{NO}_{2}\right.$ in $\mathrm{N}_{2}$, Praxair), diluted with zero air, and added to the system at the inlet tip. The accuracy of the $\mathrm{NO}_{2}$ detection is $\pm 5 \%$ due the uncertainty in the concentration of the diluted calibration standard. The accuracy for the for the $\Sigma$ ANs measurement also includes terms for the completeness of thermal dissociation and the transmission efficiency through the inlet and is estimated following Day et al. (2002) to be $15 \%$. Measurement comparisons between PTR-MS and TD-LIF of an isoprene nitrate standard show the techniques to be consistent to within $10 \%$ (Perring et al., 2009b) and similar accuracy is reported for $\Sigma$ PNs when compared to various instruments (Wooldridge et al., 2010). The minimum detectable $\Sigma$ ANs signal depends on the concentration of the adjacent channel $\left(\mathrm{NO}_{2}+\Sigma \mathrm{PNs}\right)$ and the associated uncertainties of both channels and is estimated as $63 \mathrm{ppt}$ at $1 \mathrm{ppb}$ of $\mathrm{NO}_{2}+\Sigma \mathrm{PNs}$ and $20 \mathrm{ppt}$ for 100 ppt of $\mathrm{NO}_{2}+\Sigma$ PNs at $S / N=2$ on an averaging time of $10 \mathrm{~s}$ (Day et al., 2002). The TD-LIF $\Sigma$ ANs measurement includes molecules in both the gas and aerosol phase. The sampling frequency for each class of measured $\mathrm{NO}_{\mathrm{y}}$ species is $5 \mathrm{~Hz}$ and the heated inlets for this instrument were also located on the top level of the North measurement tower.

\section{Results and discussion}

\subsection{Suite of organic nitrates observed}

Chemical structures for the nitrates measured and presented here are shown in Fig. 1. The most abundant nitrate was the first generation isoprene hydroxynitrates; this measurement is a sum of isomers. Second generation nitrates from isoprene 


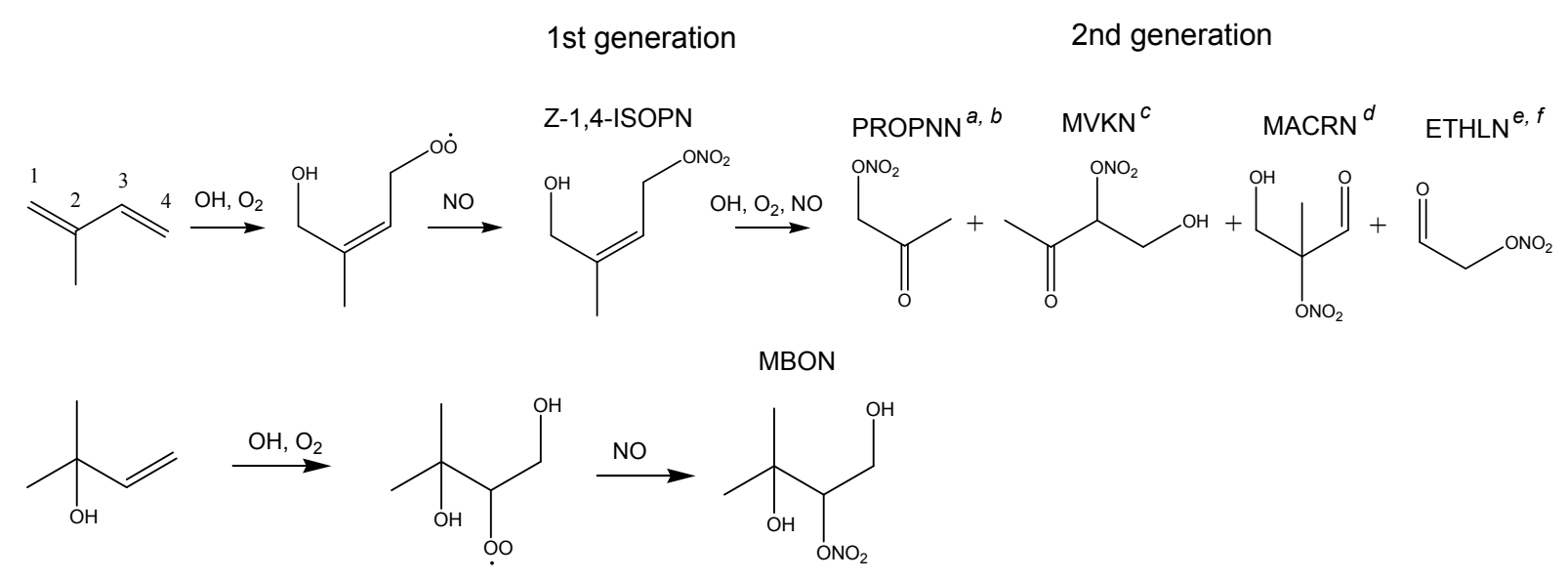

Fig. 1. Organic nitrates from isoprene and MBO photooxidation observed in this study. Only one isoprene hydroxynitrate from the eight possible isoprene nitrate isomers is shown here. Only ETHLN forms from the isoprene hydroxynitrate isomer shown here. The other second generation nitrates can form from the isomers indicated by the superscripted letters (a: 4,1-ISOPN; b: 2,1-ISOPN; c: 4,3-ISOPN; d: 1,2ISOPN; e: 3,4-ISOPN; f: 1,4-ISOPN, shown).

including PROPNN, MVKN, MACRN, and ETHLN were also observed. MVKN and MACRN are isobaric, therefore, our measurement is assumed to be a sum of these species. MVKN and MACRN can also form from the oxidation of MVK and MACR. A signal attributed to MBON, a dihydroxynitrate, was also measured. Each of these species has been previously observed and identified using CIMS in laboratory experiments (Paulot et al., 2009a; Chan et al., 2009). Time series and average diurnal profiles for each of the nitrates in Fig. 1 and $\Sigma$ ANs are shown in Fig. 2.

All data are presented using Pacific Standard Time (PST). Although isoprene is not a major local emission, the isoprene hydroxynitrate is the most abundant of the nitrates observed at the BEARPEX site. MBON was less abundant than all other organic nitrates except the two carbon ETHLN. Diurnal profiles shown in red are mean concentrations on days with maximum daytime temperatures of $26^{\circ} \mathrm{C}$ and higher. Blue diurnal profile is the mean concentration on days with maximum temperatures less than $26^{\circ} \mathrm{C}$. This division roughly corresponds to the noticeable increase in nitrate concentrations observed around Julian day 195. Biogenic precursor emissions should be higher at the warmer temperatures; also, more rapid photochemistry is likely at the warmer temperatures (Day et al., 2008). For the isoprene hydroxynitrates and its degradation products, the diurnal profiles look very similar to advected chemical species such as anthropogenic VOCs, CO, and nitrogen oxides (Murphy et al., 2007; Day et al., 2009; Lamanna and Goldstein, 1999). These chemical species have afternoon or evening maxima between the hours of 16 and 21. MBON peaks at noon consistent with more local VOC photochemistry. The secondary MBON peak around hour 8 is similar to observations of morning peaks in $\mathrm{NO}_{\mathrm{x}}$ (Day et al., 2009) and biogenic VOCs (Schade et al., 2000). These morning peaks have been attributed to downward mixing of the nocturnal residual layer. The differences in the diurnal patterns of this suite of organic nitrates reflect the different VOC sources relative to the site location. Also, the observations of the second generation ETHLN and PROPNN indicate the ISOPN likely form upwind of the BEARPEX forest location and are oxidized during the transport to the site.

Ambient measurements of isoprene nitrates are rare, but have been conducted over two forested locations in Michigan and Tennessee using gas chromatography followed by pyrolytic conversion to and subsequent detection of $\mathrm{NO}_{2}$ (Grossenbacher et al., 2004, 2001). This technique speciates the isomers of the isoprene nitrates, in contrast to the measurement made here which is the sum of the isomers. The two locations were characterized by vastly different concentrations of isoprene nitrates, with average, midday concentrations at the Tennessee site 5-10 times greater than observed at the Michigan forest site (mean, midday $\sim 10 \mathrm{pptv}$ ). The authors explained these datasets by the differences in the photochemical age of the two different airmasses. The isoprene emissions were much closer in proximity, therefore fresher and less processed at the Michigan forest site when compared with the Tennessee site. Our measurements are generally much higher than observed at either the Michigan or Tennessee sites, which can likely be explained by differences in location, season, oxidative environment, and measurement methods (individual isomers vs. the sum of the isomers).

\subsection{Alkyl nitrates budget}

Though $\Sigma$ ANs have been measured at this site previously, speciation of the hydroxynitrates has not been performed. A comparison of the speciated nitrates measured using CIMS and the $\Sigma$ ANs is shown in Fig. 3a. 

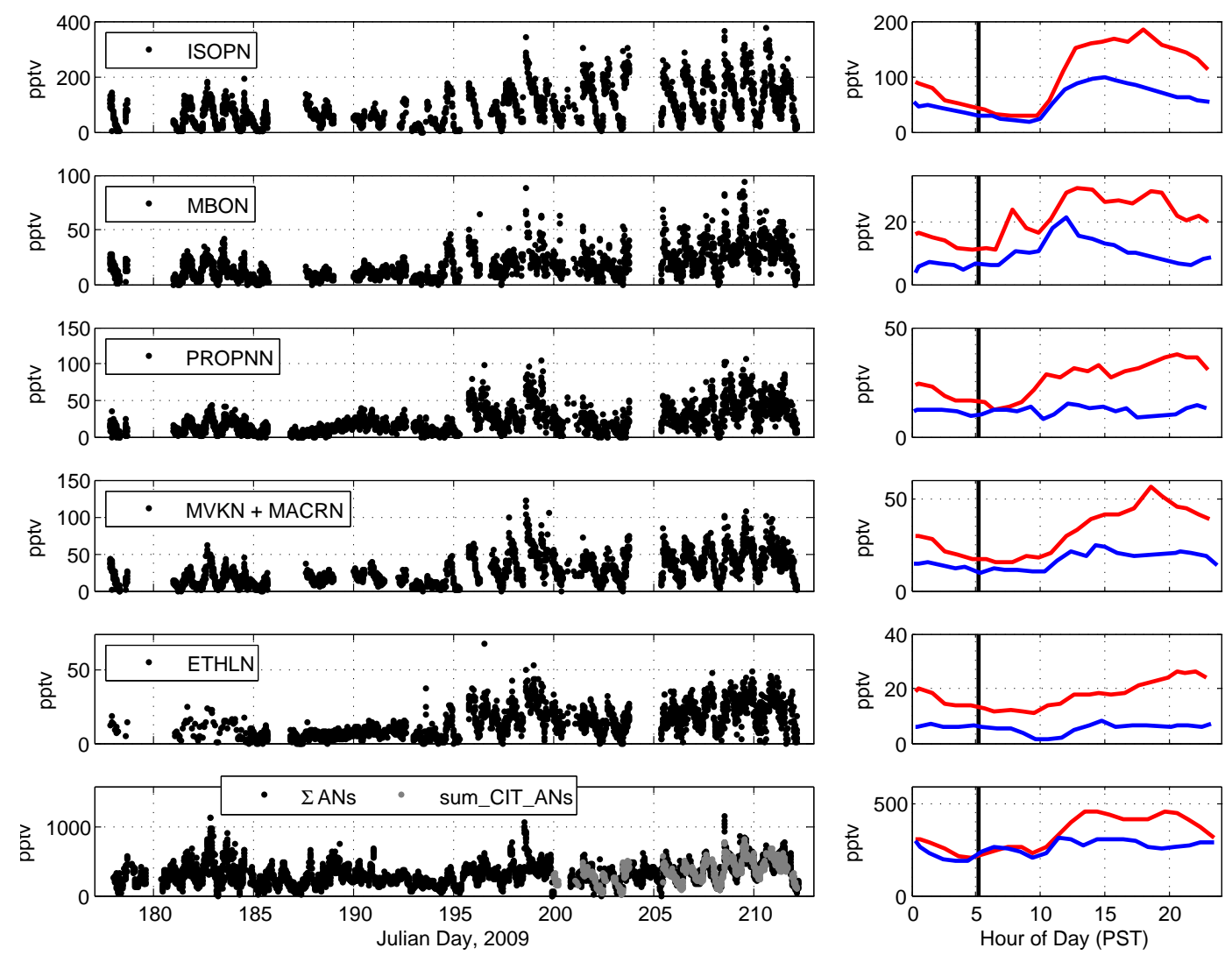

Fig. 2. Time series (left) and mean diurnal profiles (right) of organic nitrates and $\Sigma$ ANs measured during BEARPEX 2009. Diurnal profiles shown in red are mean concentrations on days with maximum daytime temperatures of $26^{\circ} \mathrm{C}$ and higher. Blue diurnal profile is the mean concentration on days with maximum temperatures less than $26^{\circ} \mathrm{C}$. Vertical lines indicate local sunrise.

The mean $\Sigma$ ANs measurement during JD 199-212 is shown as the dashed line, with the speciated organic nitrates summed in individual colors. The diurnal profile of the total alkyl nitrate meaurement also looks similar to compounds known to be transported to the site, though the maximum does occur at noon when local chemistry and emissions would be expected to be a larger contribution. When summed, the identified organic nitrates measured with the CIMS comprise two-thirds of the total alkyl nitrates at the site, averaged from noon-06:00 p.m. The fraction shown in gray is discussed below. A scatter plot of $\Sigma$ ANs vs. the sum of the speciated nitrates (ISOPN + PROPNN + MVKN + MACRN + MBON + ETHLN) is shown in Fig. 3b. These two measurement sets are well correlated with an $R^{2}$ of 0.85 .

The influence of transport on the speciation of the alkyl nitrates can be clearly seen by comparison with predictions based on local photochemical production. The production of alkyl nitrates is calculated according to Eq. (1), where $\alpha$ is the branching ratio to the formation of the organic nitrate (Rosen et al., 2004; Perring et al., 2010), and $F_{i}$ is the fraction of peroxy radicals reacting with NO. Data used to calculate the contributions of each VOC to alkyl nitrate production are shown in Table 1.

$$
P(\mathrm{ANs})=\sum \alpha_{i} k_{\mathrm{OH}+\mathrm{VOC}_{i}} F_{i}[\mathrm{OH}]\left[\mathrm{VOC}_{\mathrm{i}}\right]
$$

VOC concentrations were measured using GC-FID, and the afternoon mean from 12:00-18:00 PST is used in this analysis. This type of analysis is limited by using only the VOC measurements at the site. It is possible these VOC measurements are missing a VOC which is a large local source of nitrates or a VOC that is a large nitrate source upwind is no longer present in the air mass once it reaches the forest and is measured.

The fraction of peroxy radicals from each VOC precursor expected to react with $\mathrm{NO}, F_{i}$, has been estimated based on local, average midday $\mathrm{NO}(65 \mathrm{pptv})$ and $\mathrm{HO}_{2}(20 \mathrm{pptv})$ (Mao et al., 2012) concentrations at the site, along with the ratio of rate constants for the peroxy radical reactions with NO and $\mathrm{HO}_{2} . F_{i}$ is calculated using the ratio of the concentrations of $\mathrm{NO}$ to $\mathrm{NO}$ plus $\mathrm{HO}_{2}$, weighted by the ratio of rate constants for reaction with $\mathrm{NO}$ and $\mathrm{HO}_{2}$. For both isoprene and methacrolein, recently proposed peroxy radical isomerizations compete, to varying degrees, with $\mathrm{NO}$ and $\mathrm{HO}_{2}$ reactions (Peeters et al., 2009; Crounse et al., 2011, 2012). For isoprene, using the experimentally derived peroxy radical 

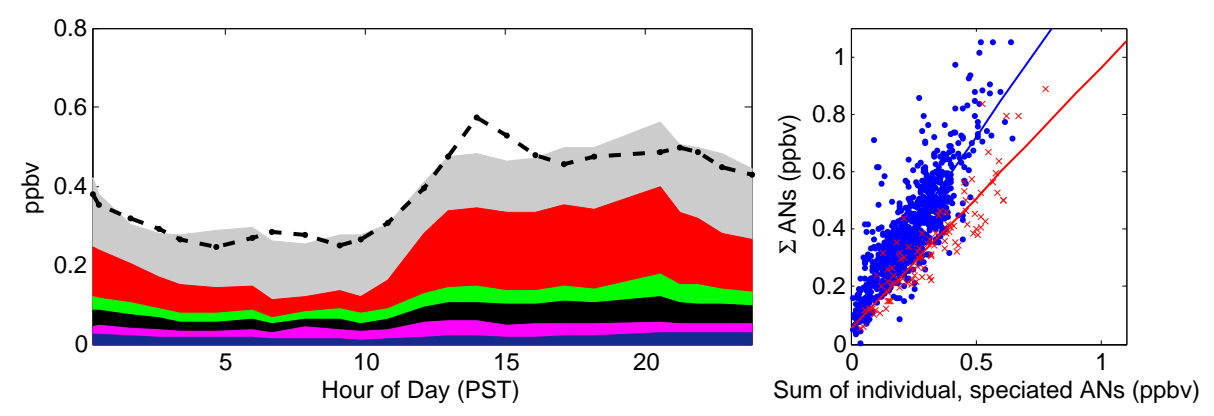

Fig. 3. (a) Comparison of CIMS and TD-LIF measurements during the last two weeks of the campaign (Julian days 199-212). $\Sigma$ ANs as measured by TD-LIF are shown as the dashed line. Speciated organic nitrates are shown in the colors. The gray fraction represents the sum of other organic nitrate species observed with the CIMS (Table 2). Red $=$ ISOPN, Green $=$ PROPNN, Black $=$ MVKN + MACRN, Magenta $=$ MBON, Blue = ETHLN. (b) In blue, $\Sigma$ ANs (measured with TD-LIF) vs. the sum of individual nitrates (measured with CIMS), not including the data in the gray portion. Equation for the linear fit is $y=1.25 x+0.096, R^{2}=0.85$. In red, $\Sigma$ ANs (measured with TD-LIF) vs. the sum of individual nitrates (measured with CIMS), including the data in the gray portion. Equation for the linear fit is $y=0.91 x+0.052, R^{2}=0.89$. There are fewer data points for the data shown in red due to the frequency of data points (approximately once every $1.6 \mathrm{~h}$ ).

isomerization rate constant derived by Crounse et al. (2011), the fraction of isoprene-derived peroxy radicals reacting with NO decreases to $58 \%$ (65\% is estimated if only reactions with $\mathrm{NO}$ and $\mathrm{HO}_{2}$ are considered), with approximately $9 \%$ of the peroxy radicals undergoing isomerization reactions. Using the theoretically-calculated rate of Peeters and Muller (2010), as adopted in the recent study by (Taraborrelli et al., 2012), only $10 \%$ of the peroxy radicals would react with NO as the vast majority of these radicals are predicted to undergo isomerization, decreasing the expected contribution of isoprene nitrates to total alkyl nitrates at the site; these values are shown in parentheses in Table 1. Crounse et al. (2012) has recently shown the yield of nitrates following addition of $\mathrm{OH}$ to MACR is about $6 \%$. Because there are two channels in the $\mathrm{OH}$ chemistry, the effective yield from reaction of $\mathrm{OH}$ with MACR is only $\sim 50 \%$ of this value (e.g. $3 \%$ ). However, Crounse et al. (2012) show that for atmospheric conditions like those at BEARPEX $([\mathrm{NO}]<1 \mathrm{ppb})$, essentially none of the peroxy radicals formed following addition of $\mathrm{OH}$ will react with $\mathrm{NO}$ due to fast peroxy radical isomerization reaction. Thus, we have used zero for the fraction of methacrolein derived peroxy radicals reacting with NO. The effects of these peroxy radical isomerization reactions on oxidation product distribution will be more fully explored in a future publication.

Branching ratios, $\alpha$, are generally taken from MCM (v3.2) (http://mcm.leeds.ac.uk/MCM) except where noted (Saunders et al., 2003). The value of $\alpha$ for alkyl nitrates (to account for the formation of dinitrates or nitrate retaining oxidation products) is dependent on the distribution of the specific alkyl nitrates present. Here, we have assumed an $\alpha$ of 0.15 to reflect a mixture of ISOPN and other alkyl nitrates. Our calculation of the AN distribution is not very sensitive to this assumption. Daytime NO concentrations at the site were typically $\sim 65$ pptv. If the alkyl nitrates at the site are mostly affected by the local production, the atmospheric con- centrations should be reflective of the alkyl nitrate production rates. Overall, based on the VOCs measured at the site, MBO is calculated to be the largest contributor (52\%) to alkyl nitrate production, with isoprene as the second most important, contributing $35 \%$. However, the CIMS observations show that ISOPN (38\%) and second generation nitrates from ISOPN $(21 \%)$ are a much larger contribution to the alkyl nitrate budget than MBON (7\%). Perez et al. (2009), using an MCM (v3.1) based Lagrangian model of the Sacramento urban plume, predicted $68 \%$ of the alkyl nitrates at the measurement site to be lumped hydroxynitrates from the $\mathrm{OH}$ oxidation of ISOPN, $11 \%$ ISOPN, and $17 \%$ MBON. This highlights that the alkyl nitrates at the site are likely a mix of transported first and second generation isoprene nitrates as well as locally produced multifunctional nitrates such as MBON. Indeed, MBON is an even smaller component of the alkyl nitrate budget than predicted by the Lagrangian model of Perez et al. (2009). Both the measurements and the model predict the dominance of isoprene-derived nitrates, however, the model predicts the oxidation products of isoprene nitrates to dominate over the first generation isoprene nitrates.

\subsection{Possible sources of unidentified alkyl nitrates}

The speciated nitrates observed by CIMS account for approximately $65 \%$ of the total organic nitrates observed with TDLIF at the BEARPEX site. Two avenues were explored to investigate the possible sources of other organic nitrates contributing to $\Sigma$ ANs at the site. These include the investigation of the contributions of: (1) shorter chain, $\mathrm{C}_{1}-\mathrm{C}_{3}$, alkyl nitrates as measured during the BEARPEX 2007 campaign and $\mathrm{C}_{1}-\mathrm{C}_{5}$ alkyl nitrates as measured from an airborne platform during the NASA TC ${ }^{4}$ campaign over the BEARPEX site in 2007, (2) unidentified, nitrogen containing mass spectral signals from our CIMS data. 
Table 1. Locally observed and estimated alkyl nitrate VOC precursors for BEARPEX 2009. Mixing ratios (MR) are mean afternoon (12:0018:00 PST) concentrations. Nitrate yields and rate constants are from the literature as cited. ${ }^{a}$ (Paulot et al., 2009a); ${ }^{\mathrm{b}}$ (Atkinson and Arey, 2003a); ${ }^{\mathrm{c}}$ (Atkinson et al., 2006); ${ }^{\mathrm{d}}$ (Atkinson and Arey, 2003a); ${ }^{\mathrm{e}}$ estimated; ${ }^{\mathrm{f}} \mathrm{OH}=6 \times 10^{6}$ molecules cm ${ }^{-3}$ (Bouvier-Brown et al., 2009 ; Wolfe et al., 2011; Dreyfus et al., 2002); ${ }^{\mathrm{g}}$ MCMv3.2 (Saunders et al., 2003); ${ }^{\mathrm{h}}$ Chan et al. (2009); ${ }^{\mathrm{i}}$ assumed to have the same yield as the pinenes; ${ }^{\mathrm{j}}$ (Crounse et al., 2012); ${ }^{\mathrm{k}}$ estimated; ${ }^{1}$ (Crounse et al., 2011); ${ }^{\mathrm{m}}$ rate constant scaled to reflect only OH addition pathways, from MCMv3.2 (Saunders et al., 2003); ${ }^{\mathrm{n}}$ values given in parentheses show the fractional contribution of each VOC to alkyl nitrate production if an isoprene peroxy radical isomerization rate constant from Peeters and Muller (2010) is used.

\begin{tabular}{llllllll}
\hline VOC & MR (ppbv) & $\alpha$ & $k_{\mathrm{OH}+\mathrm{VOC}}$ & $F_{i}$ & $P_{\mathrm{ANs}}\left(\mathrm{ppb} \mathrm{h}^{-1}\right)^{\mathrm{f}}$ & $\operatorname{frac}_{\mathrm{ANs}}\left(\operatorname{frac} P_{\text {ANs_ISOM }}\right)^{\mathrm{n}}$ \\
\hline ANs & 0.5 & $0.15^{\mathrm{k}}$ & $5.0 \mathrm{e}-11^{\mathrm{a}}$ & 0.65 & 0.05 & 0.08 & $(0.10)$ \\
benzene & 0.029 & $0.03^{\mathrm{g}}$ & $4.2 \mathrm{e}-13^{\mathrm{b}, \mathrm{m}}$ & 0.63 & 0.0 & 0.0 & $(0.0)$ \\
toluene & 0.128 & $0.08^{\mathrm{g}}$ & $4.0 \mathrm{e}-12^{\mathrm{b}, \mathrm{m}}$ & 0.61 & 0.0 & 0.0 & $(0.0)$ \\
isoprene & 1.91 & $0.10^{\mathrm{g}}$ & $1.0 \mathrm{e}-10^{\mathrm{c}}$ & $0.58\left(0.10^{\mathrm{l}}\right)$ & 0.24 & 0.35 & $(0.08)$ \\
MVK & 1.11 & $0.01^{\mathrm{g}}$ & $2.0 \mathrm{e}-11^{\mathrm{c}}$ & 0.67 & 0.0 & 0.0 & $(0.01)$ \\
MACR & 0.43 & $0.06^{\mathrm{j}}$ & $1.6 \mathrm{e}-11^{\mathrm{c}, \mathrm{m}}$ & $\sim 0.0^{\mathrm{j}}$ & 0.0 & 0.0 & $(0.0)$ \\
$\beta$-pinene & 0.12 & $0.2^{\mathrm{g}}$ & $7.7 \mathrm{e}-11^{\mathrm{d}}$ & 0.58 & 0.02 & 0.03 & $(0.04)$ \\
$\alpha$-pinene & 0.15 & $0.2^{\mathrm{g}}$ & $5.3 \mathrm{e}-11^{\mathrm{c}}$ & 0.58 & 0.02 & 0.03 & $(0.04)$ \\
MBO & 4.5 & $0.10^{\mathrm{h}}$ & $5.8 \mathrm{e}-11^{\mathrm{d}}$ & 0.65 & 0.36 & 0.52 & $(0.72)$ \\
camphene & 0.018 & $0.2^{i}$ & $5.3 \mathrm{e}-11^{\mathrm{d}}$ & 0.58 & 0.0 & 0.0 & $(0.1)$ \\
methane & $1800^{\mathrm{e}}$ & $0.001^{\mathrm{g}}$ & $6.4 \mathrm{e}-15^{\mathrm{c}}$ & 0.83 & 0.0 & 0.0 & $(0.0)$ \\
TOTAL & & & & & 0.70 & & \\
\hline
\end{tabular}

Though the CIMS technique has been shown to measure two and three carbon multifunctional nitrates, the technique is not sensitive to shorter carbon chain, monofunctional alkyl nitrates such as methyl, ethyl, and propyl nitrate; it is possible some fraction of the nitrates unidentified by the CIMS are composed of these alkyl nitrates. These compounds are derived from anthropogenic VOCs, and are formed in or near Sacramento and transported to the site. A GC-MS was used during the BEARPEX 2007 (August-October) campaign to measure $\mathrm{C}_{1}-\mathrm{C}_{3}$ alkyl nitrates. The sum of these species was generally $<20$ pptv (J. deGouw and J. Gilman, personal communication, 2009). During $\mathrm{TC}^{4}$, the NASA DC8 aircraft flew over the BEARPEX location (10 August 2007) before landing in Sacramento. Whole air samples were collected inflight, and analyzed off-line using GC-FID. The aircraft was at a pressure altitude of $<3.5 \mathrm{~km}$ when near the site, and decreased in altitude before landing in Sacramento. During this transect, the $\mathrm{C}_{1}-\mathrm{C}_{5}$ alkyl nitrates peak concentration was 25 pptv, at the lowest altitude, just before landing (D. Blake, personal communication, 2010). Thus, neither of these measurements indicate small chain, alkyl nitrates are a large component of the alkyl nitrate budget at or near the BEARPEX site.

Mass spectral identification of nitrogen containing compounds benefits from the odd number of valence electrons in nitrogen. Parent ions or fragments of organic compounds containing an odd number of nitrogen atoms have an odd molecular weight (McLafferty and Turecek, 1993). Thus, with the CIMS technique used here, the $\mathrm{CF}_{3} \mathrm{O}^{-}$cluster with a nitrogen containing compound has an even mass. Since dinitrates do not have an odd molecular weight, any dinitrates would not be identified using this analysis. All identified or-
Table 2. Significant nitrogen-containing $\mathrm{m} / \mathrm{z}$ observed with the CIMS. The $m / z$ column indicates the signal in the mass spectrum. The m.w. column is the inferred molecular weight $(m / z-85)$. The letters in the proposed structure column designated the corresponding structures shown in Fig. 4.

\begin{tabular}{cccc}
\hline$m / z$ & m.w. & max MR (ppt) & proposed structure \\
\hline 220 & 135 & 10 & - \\
230 & 145 & 28 & $\mathrm{a}$ \\
236 & 151 & 5 & - \\
244 & 159 & 30 & - \\
246 & 161 & 11 & - \\
248 & 163 & 44 & $\mathrm{~b}$ \\
262 & 177 & 16 & - \\
300 & 215 & 30 & $\mathrm{c}$ \\
316 & 231 & 44 & $\mathrm{~d}$ \\
\hline
\end{tabular}

ganic nitrates presented here have even $m / z$. As deployed during this campaign (starting with julian day 199), the instrument was set to scan all $\mathrm{m} / \mathrm{z}$ ratios up to $\mathrm{m} / \mathrm{z} 325$ approximately once every two hours. In Fig. 3a, gray portion, we sum the signals from the nine even $m / z$ that carry essentially all the additional intensity from nitrogen containing compounds. In the absence of sensitivity calculations for each species, a CIMS sensitivity equal to the sensitivity for ISOPN has been applied to these signals. The summed $\mathrm{m} / \mathrm{z}$ are listed in Table 2. Possible structures for four of the nine even $m / z$ compounds are shown in Fig. 4.

Signals at $\mathrm{m} / z 230$ and $\mathrm{m} / z 248$ have been observed in smog chamber isoprene $+\mathrm{NO}_{3}$ experiments $(\mathrm{Ng}$ et al., 2008). Since vegetative emission of isoprene is known to be 
a) $\mathrm{m} / \mathrm{z} 230$

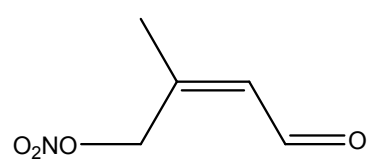

b) $\mathrm{m} / \mathrm{z} 248$

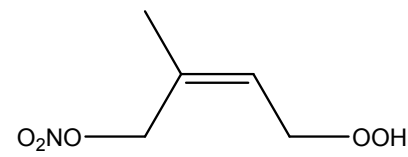

c) $\mathrm{m} / \mathrm{z} 300$<smiles></smiles>

d) $\mathrm{m} / \mathrm{z} 316$

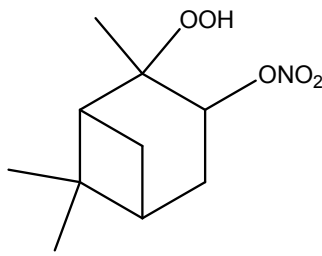

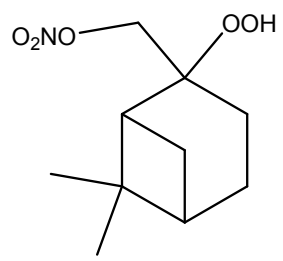

Fig. 4. Proposed structures for even mass signals listed in Table 2. $m / z 248$ could also be due to $\mathrm{MBO}+\mathrm{NO}_{3}$ chemistry, but since the $\mathrm{NO}_{3}$ rate constant is $\sim 500$ times lower than with $\alpha$-pinene, and $\sim 60$ times lower than isoprene, it is expected to be a minimal contribution.

light-dependent, no isoprene is emitted at night, when nitrate radical chemistry would be expected to be active. However, isoprene emitted late in the day when photochemical oxidants are low has been found to be oxidized by the nitrate radical (Brown et al., 2009; Starn et al., 1998). Near the end of the day, as well as during cloudy and stable conditions, reactions with BVOCs and other hydrocarbons can be a significant loss for nitrate radicals (Geyer et al., 2003). Specifically, the proposed structure for $m / z 230$ is a product from isoprene $+\mathrm{NO}_{3}$ chemistry, forming a nitrooxyperoxy radical, which upon further reaction with $\mathrm{RO}_{2}$ or $\mathrm{NO}_{3}$ can form the $\mathrm{C}_{5^{-}}$nitrooxycarbonyl. This compound, the $\mathrm{C}_{5}$-nitrooxycarbonyl, could also result from $\mathrm{OH}$-initiated oxidation of ISOPN via $\mathrm{H}$-abstraction from the carbon alpha to the $\mathrm{OH}$ group, however, this product has not been observed to be a significant product of ISOPN photooxidation in smog chamber experiments (Paulot et al., 2009a). The structure proposed for $\mathrm{m} / \mathrm{z}$

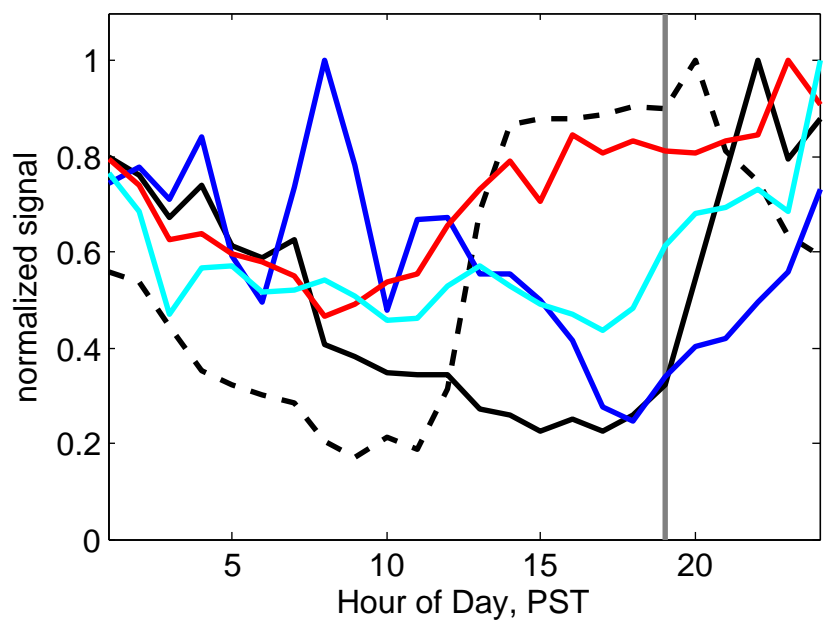

Fig. 5. Average, normalized diurnal signal of the $m / z 316$ product, proposed as the nitrooxyhydroperoxide from $\alpha$-pinene (solid black line); $m / z 300$ product, proposed as the hydroxynitrate from $\alpha$-pinene (solid blue line); $m / z 248$ product, proposed as the nitrooxyhydroperoxide from isoprene (solid red line); $m / z$ 230, proposed as the nitrooxycarbonyl from isoprene (solid cyan line). For reference, the signal for ISOPN is shown as the dashed line. The solid gray line indicates the approximate time of local sunset.

248 is also a product of isoprene $+\mathrm{NO}_{3}$ chemistry; to form this product, the nitrooxyperoxy radical reacts with $\mathrm{HO}_{2}$ to form the $\mathrm{C}_{5}$-nitrooxyhydroperoxide. The signal at $\mathrm{m} / \mathrm{z} 248$ could also result from $\mathrm{MBO}+\mathrm{NO}_{3}$ chemistry, however, the lifetime of $\mathrm{MBO}$ with respect to $\mathrm{NO}_{3}$, for conditions relevant to the site is expected to be longer than a month (Atkinson and Arey, 2003a).

We propose a nitrooxyhydroperoxide structure for the $\mathrm{m} / \mathrm{z}$ 316 signal orginating from $\alpha$ - and $\beta$-pinene, and two possible structures resulting from $\alpha$-pinene are shown in Fig. 4. These monoterpenes are generally modeled as temperature dependent emissions, and can be emitted at night when $\mathrm{NO}_{3}$ chemistry is important (Sakulyanontvittaya et al., 2008). Nighttime $\mathrm{HO}_{2}$ radical concentrations were generally 3-4 pptv (Mao et al., 2012). Nighttime concentrations of $\mathrm{NO}_{3}$ of 1 pptv have been predicted at the measurement site (BouvierBrown et al., 2009). The lifetime of $\alpha$-pinene with respect to $\mathrm{NO}_{3}$ (1 pptv) and $\mathrm{O}_{3}$ (55 ppbv) is $220 \mathrm{~min}$ and $170 \mathrm{~min}$, respectively, so nitrate radical chemistry is expected to compete with ozonolysis for $\alpha$-pinene oxidation at night. It is hypothesized this product might form an isobaric epoxide compound upon oxidation by OH (Paulot et al., 2009b). The proposed structure for the signal at $m / z 300$ results from the photooxidation of $\alpha$-or $\beta$-pinene, and has been observed in smog chamber photooxidation experiments of $\alpha$-pinene in the presence of $\mathrm{NO}_{\mathrm{x}}$ (Eddingsaas et al., 2012). The diurnal profiles of these signals (solid lines) are shown in Fig. 5 in comparison to the ISOPN nitrate signal (dashed line). 
The diurnal profiles of the $m / z 316$ signal peaks at night, suggesting the formation of this product from nocturnal chemistry, combined with a long atmospheric lifetime. The profiles of $\mathrm{m} / \mathrm{z} 230$ and 248 also peak at night, supporting the proposal of the role of nitrate radical chemistry in their formation. If these four tentatively identified nitrates, and the five other unidentified nitrates listed in Table 2 are included in the comparison between the CIMS and TD-LIF, the two measurements are in close agreement, Fig. 3b. The timeseries of all CIMS identified nitrates, including these additional nitrates, are included on the bottom panel of Fig. 2.

Several of the proposed structures highlight the importance of nocturnal, nitrate radical chemistry at this rural, forested location. The formation of two of these structures requires reaction with $\mathrm{HO}_{2}$ after reaction with $\mathrm{NO}_{3}$. This chemistry is challenging to study in nitrate radical driven chamber experiments that can often be dominated by $\mathrm{RO}_{2}+\mathrm{RO}_{2}$ reactions. Therefore, even at much lower $\mathrm{HO}_{2}$ concentrations than encountered during peak photochemistry, $\mathrm{HO}_{2}$ contributes to radical reactivity at night.

Another possible explanation for the unidentified organic nitrates measured by the TD-LIF instrument and not by the CIMS could be a difference in phase (gas or aerosol) of the organic nitrogen. The TD-LIF technique was operated in the field using no filter/denuder on the inlet, so the measurement should be considered the sum of gas and aerosol phase alkyl nitrates. The CIMS technique does not convert aerosol particles to the gas phase, therefore the technique only measures the gas phase contribution to the organic nitrates. Rollins et al. (2010) have recently shown the TD-LIF technique measures both gas and aerosol phase organic nitrates, and found $15-18 \%$ of the SOA formed from $\alpha$-pinene photooxidation, initiated by $\mathrm{OH}$ oxidation, under high $\mathrm{NO}_{\mathrm{x}}$ conditions was composed of alkyl nitrates. Fry et al. (2009) found 32-41\% of the aerosol mass formed in the $\beta$-pinene $+\mathrm{NO}_{3}$ reaction was from organic nitrogen. It is possible that daytime and nocturnal oxidation of the monoterpene species at the site result in organic nitrates that partition into the aerosol phase, therefore the TD-LIF would be sensitive to the compounds and the CIMS would not. However, no aerosol organic nitrogen measurement during this campaign is available to evaluate this possibility.

\section{Summary and conclusions}

Observations of speciated and total alkyl and multifunctional nitrates over a ponderosa pine forest in the Sierra Nevada during the summer show total alkyl nitrates to be composed primarily of biogenically produced nitrates. First and second generation nitrates from isoprene along with a nitrate from MBO account for two-thirds of the alkyl nitrates at the site. Based on these measurements, the organic nitrates at the site are from a mix of locally produced and transported nitrates formed from photochemical and nighttime chemistry. These measurements highlight the interaction of the Sacramento urban plume with the forested areas downwind. Similar results would be expected from other forested areas downwind of urban areas. As areas of the tropics are developed, the impact of biogenically derived organic nitrates on ozone formation will become ever more significant.

Acknowledgements. This research was supported by the National Science Foundation (grants ATM-0934408 and ATM-0934345). We thank Sierra Pacific Industries for the use of their land, and the University of California, Berkeley, Center for Forestry, Blodgett Forest Research Station for cooperation in facilitating this research. MRB also thanks Ying Xie (US EPA) and Ellie Browne (UCB) for helpful comments on the manuscript.

Edited by: J. Williams

\section{References}

Alvarado, A., Tuazon, E. C., Aschmann, S. M., Arey, J., and Atkinson, R.: Products and mechanisms of the gas-phase reactions of $\mathrm{OH}$ radicals and O-3 with 2-methyl-3-buten-2-ol, Atmos. Environ., 33, 2893-2905, doi:10.1016/S1352-2310(99)00106-5, 1999.

Aschmann, S. M., Atkinson, R., and Arey, J.: Products of reaction of OH radicals with alpha-pinene, J. Geophys. Res.-Atmos., 107, 4191, doi:10.1029/2001JD001098, 2002.

Atkinson, R. and Arey, J.: Gas-phase tropospheric chemistry of biogenic volatile organic compounds: a review, Atmos. Environ., 37, S197-S219, doi:10.1016/S1352-2310(03)00391-1, 2003a.

Atkinson, R. and Arey, J.: Atmospheric degradation of volatile organic compounds, Chem. Rev., 103, 4605-4638, doi:10.1021/cr0206420, 2003b.

Atkinson, R., Baulch, D. L., Cox, R. A., Crowley, J. N., Hampson, R. F., Hynes, R. G., Jenkin, M. E., Rossi, M. J., Troe, J., and IUPAC Subcommittee: Evaluated kinetic and photochemical data for atmospheric chemistry: Volume II - gas phase reactions of organic species, Atmos. Chem. Phys., 6, 3625-4055, doi:10.5194/acp-6-3625-2006, 2006.

Barnes, I., Bastian, V., Becker, K. H., and Tong, Z.: Kinetics and products of the reactions of NO3 with monoalkenes, dialkenes, and monoterpenes, J. Phys. Chem., 94, 2413-2419, doi:10.1021/j100369a041, 1990.

Bouvier-Brown, N. C., Goldstein, A. H., Gilman, J. B., Kuster, W. C., and de Gouw, J. A.: In-situ ambient quantification of monoterpenes, sesquiterpenes, and related oxygenated compounds during BEARPEX 2007: implications for gas- and particle-phase chemistry, Atmos. Chem. Phys., 9, 5505-5518, doi:10.5194/acp-9-5505-2009, 2009.

Brown, S. S., deGouw, J. A., Warneke, C., Ryerson, T. B., Dubé, W. P., Atlas, E., Weber, R. J., Peltier, R. E., Neuman, J. A., Roberts, J. M., Swanson, A., Flocke, F., McKeen, S. A., Brioude, J., Sommariva, R., Trainer, M., Fehsenfeld, F. C., and Ravishankara, A. R.: Nocturnal isoprene oxidation over the Northeast United States in summer and its impact on reactive nitrogen partitioning and secondary organic aerosol, Atmos. Chem. Phys., 9, 30273042, doi:10.5194/acp-9-3027-2009, 2009. 
Carter, W. P. L. and Atkinson, R.: Alkyl nitrate formation from the atmospheric photooxidation of alkanes - A revised estimation method, J. Atmos. Chem., 8, 165-173, doi:10.1007/BF00053721, 1989.

Chan, A. W. H., Galloway, M. M., Kwan, A. J., Chhabra, P. S., Keutsch, F. N., Wennberg, P. O., Flagan, R. C., and Seinfeld, J. H.: Photooxidation of 2-Methyl-3-Buten-2-ol (MBO) as a Potential Source of Secondary Organic Aerosol, Environ. Sci. Technol., 43, 4647-4652, doi:10.1021/es902789a, 2009.

Chen, X. H., Hulbert, D., and Shepson, P. B.: Measurement of the organic nitrate yield from $\mathrm{OH}$ reaction with isoprene, J. Geophys. Res.-Atmos., 103, 25563-25568, doi:10.1029/98JD01483, 1998.

Chuong, B. and Stevens, P. S.: Measurements of the kinetics of the OH-initiated oxidation of isoprene, J. Geophys. Res.-Atmos., 107, 4162, doi:10.1029/2001JD000865, 2002.

Crounse, J. D., McKinney, K. A., Kwan, A. J., and Wennberg, P. O.: Measurement of gas-phase hydroperoxides by chemical ionization mass spectrometry, Anal. Chem., 78, 6726-6732, doi:10.1021/ac0604235, 2006.

Crounse, J. D., Paulot, F., Kjaergaard, H. G., and Wennberg, P. O.: Peroxy radical isomerization in the oxidation of isoprene, Phys. Chem. Chem. Phys., 13, 13607-13613, doi:10.1039/c1cp21330j, 2011.

Crounse, J. D., Knap, H. C., Ornso, K. B., Jorgensen, S., Paulot, F., Kjaergaard, H. G., and Wennberg, P. O.: On the Atmospheric Fate of Methacrolein: 1. Peroxy Radical Isomerization Following Addition of $\mathrm{OH}$ and $\mathrm{O}_{2}$, J. Phys. Chem. A, 16, 5756-5762, doi:10.1021/jp211560u, 2012.

Day, D. A., Farmer, D. K., Goldstein, A. H., Wooldridge, P. J., Minejima, C., and Cohen, R. C.: Observations of $\mathrm{NO}_{\mathrm{x}}, \Sigma \mathrm{PNs}$, $\Sigma \mathrm{ANs}$, and $\mathrm{HNO}_{3}$ at a Rural Site in the California Sierra Nevada Mountains: summertime diurnal cycles, Atmos. Chem. Phys., 9, 4879-4896, doi:10.5194/acp-9-4879-2009, 2009.

Day, D. A., Wooldridge, P. J., and Cohen, R. C.: Observations of the effects of temperature on atmospheric $\mathrm{HNO}_{3}, \Sigma$ ANs, $\Sigma$ PNs, and $\mathrm{NO}_{\mathrm{x}}$ : evidence for a temperature-dependent $\mathrm{HO}_{\mathrm{x}}$ source, Atmos. Chem. Phys., 8, 1867-1879, doi:10.5194/acp-8-1867-2008, 2008.

Day, D. A., Farmer, D. K., Goldstein, A. H., Wooldridge, P. J., Minejima, C., and Cohen, R. C.: Observations of $\mathrm{NO}_{\mathrm{x}}, \Sigma \mathrm{PNs}$, $\Sigma \mathrm{ANs}$, and $\mathrm{HNO}_{3}$ at a Rural Site in the California Sierra Nevada Mountains: summertime diurnal cycles, Atmos. Chem. Phys., 9, 4879-4896, doi:10.5194/acp-9-4879-2009, 2009.

Dillon, M. B., Lamanna, M. S., Schade, G. W., Goldstein, A. H., and Cohen, R. C.: Chemical evolution of the Sacramento urban plume: Transport and oxidation, J. Geophys. Res.-Atmos., 107, 4045, doi:10.1029/2001JD000969, 2002.

Dreyfus, G. B., Schade, G. W., and Goldstein, A. H.: Observational constraints on the contribution of isoprene oxidation to ozone production on the western slope of the Sierra Nevada, California, J. Geophys. Res.-Atmos., 107, 4365, doi:10.1029/2001JD001490, 2002.

Eddingsaas, N. C., Loza, C. L., Yee, L. D., Seinfeld, J. H., and Wennberg, P. O.: $\alpha$-pinene photooxidation under controlled chemical conditions - Part 1: Gas-phase composition in lowand high- $\mathrm{NO}_{\mathrm{x}}$ environments, Atmos. Chem. Phys. Discuss., 12, 6447-6483, doi:10.5194/acpd-12-6447-2012, 2012.

Farmer, D. K., Perring, A. E., Wooldridge, P. J., Blake, D. R., Baker, A., Meinardi, S., Huey, L. G., Tanner, D., Vargas, O., and Co- hen, R. C.: Impact of organic nitrates on urban ozone production, Atmos. Chem. Phys., 11, 4085-4094, doi:10.5194/acp-11-40852011, 2011.

Fischer, R. G., Kastler, J., and Ballschmiter, K.: Levels and pattern of alkyl nitrates, multifunctional alkyl nitrates, and halocarbons in the air over the Atlantic Ocean, J. Geophys. Res.-Atmos., 105, 14473-14494, doi:10.1029/1999JD900780, 2000.

Fry, J. L., Kiendler-Scharr, A., Rollins, A. W., Wooldridge, P. J., Brown, S. S., Fuchs, H., Dubé, W., Mensah, A., dal Maso, M., Tillmann, R., Dorn, H.-P., Brauers, T., and Cohen, R. C.: Organic nitrate and secondary organic aerosol yield from $\mathrm{NO}_{3}$ oxidation of $\beta$-pinene evaluated using a gas-phase kinetics/aerosol partitioning model, Atmos. Chem. Phys., 9, 14311449, doi:10.5194/acp-9-1431-2009, 2009.

Garden, A. L., Paulot, F., Crounse, J. D., Maxwell-Cameron, I. J., Wennberg, P. O., and Kjaergaard, H. G.: Calculation of conformationally weighted dipole moments useful in ionmolecule collision rate estimates, Chem. Phys. Lett., 474, 45-50, doi:10.1016/j.cplett.2009.04.038, 2009.

Geyer, A., Alicke, B., Ackermann, R., Martinez, M., Harder, H., Brune, W., di Carlo, P., Williams, E., Jobson, T., Hall, S., Shetter, R., and Stutz, J.: Direct observations of daytime $\mathrm{NO}_{3}: \mathrm{Im}-$ plications for urban boundary layer chemistry, J. Geophys. Res.Atmos., 108, 4368, doi:10.1029/2002jd002967, 2003.

Goldstein, A. H., Hultman, N. E., Fracheboud, J. M., Bauer, M. R., Panek, J. A., Xu, M., Qi, Y., Guenther, A. B., and Baugh, W.: Effects of climate variability on the carbon dioxide, water, and sensible heat fluxes above a ponderosa pine plantation in the Sierra Nevada (CA), Agr. Forest Meteorol., 101, 113-129, doi:10.1016/S0168-1923(99)00168-9, 2000.

Grossenbacher, J. W., Couch, T., Shepson, P. B., Thornberry, T., Witmer-Rich, M., Carroll, M. A., Faloona, I., Tan, D., Brune, W., Ostling, K., and Bertman, S.: Measurements of isoprene nitrates above a forest canopy, J. Geophys. Res.-Atmos., 106, 24429 24438, doi:10.1029/2001JD900029, 2001.

Grossenbacher, J. W., Barket, D. J., Shepson, P. B., Carroll, M. A., Olszyna, K., and Apel, E.: A comparison of isoprene nitrate concentrations at two forest-impacted sites, J. Geophys. Res.Atmos., 109, D11311, doi:10.1029/2003JD003966, 2004.

Guenther, A., Karl, T., Harley, P., Wiedinmyer, C., Palmer, P. I., and Geron, C.: Estimates of global terrestrial isoprene emissions using MEGAN (Model of Emissions of Gases and Aerosols from Nature), Atmos. Chem. Phys., 6, 3181-3210, doi:10.5194/acp-63181-2006, 2006.

Hallquist, M., Wangberg, I., Ljungstrom, E., Barnes, I., and Becker, K. H.: Aerosol and product yields from $\mathrm{NO}_{3}$ radical-initiated oxidation of selected monoterpenes, Environ. Sci. Technol., 33, 553-559, doi:10.1021/es980292s, 1999.

Horowitz, L. W., Fiore, A. M., Milly, G. P., Cohen, R. C., Perring, A., Wooldridge, P. J., Hess, P. G., Emmons, L. K., and Lamarque, J. F.: Observational constraints on the chemistry of isoprene nitrates over the eastern United States, J. Geophys. Res.-Atmos., 112, D12S08, doi:10.1029/2006JD007747, 2007.

Ito, A., Sillman, S., and Penner, J. E.: Effects of additional nonmethane volatile organic compounds, organic nitrates, and direct emissions of oxygenated organic species on global tropospheric chemistry, J. Geophys. Res.-Atmos., 112, D06309, doi:10.1029/2005JD006556, 2007. 
Lamanna, M. S. and Goldstein, A. H.: In situ measurements of C2-C-10 volatile organic compounds above a Sierra Nevada ponderosa pine plantation, J. Geophys. Res.-Atmos., 104, 2124721262, doi:10.1029/1999JD900289, 1999.

Lockwood, A. L., Shepson, P. B., Fiddler, M. N., and Alaghmand, M.: Isoprene nitrates: preparation, separation, identification, yields, and atmospheric chemistry, Atmos. Chem. Phys., 10, 6169-6178, doi:10.5194/acp-10-6169-2010, 2010.

Mao, J., Ren, X., Brune, W. H., Van Duin, D. M., Cohen, R. C., Park, J.-H., Goldstein, A. H., Paulot, F., Beaver, M. R., Crounse, J. D., Wennberg, P. O., DiGangi, J. P., Henry, S. B., Keutsch, F. N., Park, C., Schade, G. W., Wolfe, G. M., and Thornton, J. A.: Insights into hydroxyl measurements and atmospheric oxidation in a California forest, Atmos. Chem. Phys. Discuss., 12, 67156744, doi:10.5194/acpd-12-6715-2012, 2012.

McLafferty, F. W. and Turecek, F.: Interpretation of mass spectra, University Science Book, Sausalito, California, 4 edn., 1993.

Murphy, J. G., Day, D. A., Cleary, P. A., Wooldridge, P. J., Millet, D. B., Goldstein, A. H., and Cohen, R. C.: The weekend effect within and downwind of Sacramento - Part 1: Observations of ozone, nitrogen oxides, and VOC reactivity, Atmos. Chem. Phys., 7, 5327-5339, doi:10.5194/acp-7-5327-2007, 2007.

Ng, N. L., Kwan, A. J., Surratt, J. D., Chan, A. W. H., Chhabra, P. S., Sorooshian, A., Pye, H. O. T., Crounse, J. D., Wennberg, P. O., Flagan, R. C., and Seinfeld, J. H.: Secondary organic aerosol (SOA) formation from reaction of isoprene with nitrate radicals $\left(\mathrm{NO}_{3}\right)$, Atmos. Chem. Phys., 8, 4117-4140, doi:10.5194/acp-84117-2008, 2008.

Noziere, B., Barnes, I., and Becker, K. H.: Product study and mechanisms of the reactions of alpha-pinene and of pinonaldehyde with $\mathrm{OH}$ radicals, J. Geophys. Res.-Atmos., 104, 23645-23656, doi:10.1029/1999JD900778, 1999.

Patchen, A. K., Pennino, M. J., Kiep, A. C., and Elrod, M. J.: Direct kinetics study of the product-forming channels of the reaction of isoprene-derived hydroxyperoxy radicals with NO, Int. J. Chem. Kinet., 39, 353-361, doi:10.1002/kin.20248, 2007.

Paulot, F., Crounse, J. D., Kjaergaard, H. G., Kroll, J. H., Seinfeld, J. H., and Wennberg, P. O.: Isoprene photooxidation: new insights into the production of acids and organic nitrates, Atmos. Chem. Phys., 9, 1479-1501, doi:10.5194/acp-9-1479-2009, 2009a.

Paulot, F., Crounse, J. D., Kjaergaard, H. G., Kurten, A., St Clair, J. M., Seinfeld, J. H., and Wennberg, P. O.: Unexpected Epoxide Formation in the Gas-Phase Photooxidation of Isoprene, Science, 325, 730-733, doi:10.1126/science.1172910, 2009b.

Paulot, F., Henze, D. K., and Wennberg, P. O.: Impact of the isoprene photochemical cascade on tropical ozone, Atmos. Chem. Phys., 12, 1307-1325, doi:10.5194/acp-12-1307-2012, 2012.

Peeters, J. and Muller, J. F.: $\mathrm{HO}_{\mathrm{x}}$ radical regeneration in isoprene oxidation via peroxy radical isomerisations. II: experimental evidence and global impact, Phys. Chem. Chem. Phys., 12, 1422714235, 2010.

Peeters, J., Nguyen, T. L., and Vereecken, L.: $\mathrm{HO}_{\mathrm{x}}$ radical regeneration in the oxidation of isoprene, Phys. Chem. Chem. Phys., 11, 5935-5939, 2009.

Pérez, I. M., LaFranchi, B. W., and Cohen, R. C.: Nitrogen oxide chemistry in an urban plume: investigation of the chemistry of peroxy and multifunctional organic nitrates with a Lagrangian model, Atmos. Chem. Phys. Discuss., 9, 27099-27165, doi:10.5194/acpd-9-27099-2009, 2009.
Perring, A. E., Bertram, T. H., Wooldridge, P. J., Fried, A., Heikes, B. G., Dibb, J., Crounse, J. D., Wennberg, P. O., Blake, N. J., Blake, D. R., Brune, W. H., Singh, H. B., and Cohen, R. C.: Airborne observations of total $\mathrm{RONO}_{2}$ : new constraints on the yield and lifetime of isoprene nitrates, Atmos. Chem. Phys., 9, 14511463, doi:10.5194/acp-9-1451-2009, 2009a.

Perring, A. E., Wisthaler, A., Graus, M., Wooldridge, P. J., Lockwood, A. L., Mielke, L. H., Shepson, P. B., Hansel, A., and Cohen, R. C.: A product study of the isoprene $+\mathrm{NO}_{3}$ reaction, Atmos. Chem. Phys., 9, 4945-4956, doi:10.5194/acp-9-4945-2009, 2009b.

Perring, A. E., Bertram, T. H., Farmer, D. K., Wooldridge, P. J., Dibb, J., Blake, N. J., Blake, D. R., Singh, H. B., Fuelberg, H., Diskin, G., Sachse, G., and Cohen, R. C.: The production and persistence of $\Sigma \mathrm{RONO}_{2}$ in the Mexico City plume, Atmos. Chem. Phys., 10, 7215-7229, doi:10.5194/acp-10-72152010, 2010.

Rollins, A. W., Kiendler-Scharr, A., Fry, J. L., Brauers, T., Brown, S. S., Dorn, H.-P., Dubé, W. P., Fuchs, H., Mensah, A., Mentel, T. F., Rohrer, F., Tillmann, R., Wegener, R., Wooldridge, P. J., and Cohen, R. C.: Isoprene oxidation by nitrate radical: alkyl nitrate and secondary organic aerosol yields, Atmos. Chem. Phys., 9, 6685-6703, doi:10.5194/acp-9-6685-2009, 2009.

Rollins, A. W., Smith, J. D., Wilson, K. R., and Cohen, R. C.: Real Time In Situ Detection of Organic Nitrates in Atmospheric Aerosols, Environ. Sci. Technol., 44, 5540-5545, doi:10.1021/es100926x, 2010.

Rosen, R. S., Wood, E. C., Wooldridge, P. J., Thornton, J. A., Day, D. A., Kuster, W., Williams, E. J., Jobson, B. T., and Cohen, R. C.: Observations of total alkyl nitrates during Texas Air Quality Study 2000: Implications for O-3 and alkyl nitrate photochemistry, J. Geophys. Res.-Atmos., 109, D07303, doi:10.1029/2003JD004227, 2004.

Sakulyanontvittaya, T., Duhl, T., Wiedinmyer, C., Helmig, D., Matsunaga, S., Potosnak, M., Milford, J., and Guenther, A.: Monoterpene and sesquiterpene emission estimates for the United States, Environ. Sci. Technol., 42, 1623-1629, doi:10.1021/es800817r, 2008.

Saunders, S. M., Jenkin, M. E., Derwent, R. G., and Pilling, M. J.: Protocol for the development of the Master Chemical Mechanism, MCM v3 (Part A): tropospheric degradation of nonaromatic volatile organic compounds, Atmos. Chem. Phys., 3, 161-180, doi:10.5194/acp-3-161-2003, 2003.

Schade, G. W., Goldstein, A. H., Gray, D. W., and Lerdau, M. T.: Canopy and leaf level 2-methyl-3-buten-2-ol fluxes from a ponderosa pine plantation, Atmos. Environ., 34, 3535-3544, doi:10.1016/S1352-2310(00)00120-5, 2000.

Spencer, K. M., Beaver, M. R., Clair, J. M. St., Crounse, J. D., Paulot, F., and Wennberg, P. O.: Quantification of hydroxyacetone and glycolaldehyde using chemical ionization mass spectrometry, Atmos. Chem. Phys. Discuss., 11, 23619-23653, doi:10.5194/acpd-11-23619-2011, 2011.

Sprengnether, M., Demerjian, K. L., Donahue, N. M., and Anderson, J. G.: Product analysis of the $\mathrm{OH}$ oxidation of isoprene and 1,3-butadiene in the presence of NO, J. Geophys. Res.-Atmos., 107, 4268, doi:10.1029/2001JD000716, 2002.

St. Clair, J. M., McCabe, D. C., Crounse, J. D., Steiner, U., and Wennberg, P. O.: Chemical ionization tandem mass spectrometer for the in situ measurement of methyl hydrogen peroxide, Rev. 
Sci. Instrum., 81, 094102, doi:10.1063/1.3480552, 2010.

Starn, T. K., Shepson, P. B., Bertman, S. B., Riemer, D. D., Zika, R. G., and Olszyna, K.: Nighttime isoprene chemistry at an urban-impacted forest site, J. Geophys. Res.-Atmos., 103, 22437-22447, doi:10.1029/98JD01201, 1998.

$\mathrm{Su}, \mathrm{T}$. and Chesnavich, W. J.: Parameterization of the ion-polar molecule collision rate-constant by trajectory calculations, J. Chem. Phys., 76, 5183-5185, doi:10.1063/1.442828, 1982.

Taraborrelli, D., Lawrence, M. G., Crowley, J. N., Dillon, T. J., Gross, C. B. M., Vereecken, L., and Lelieveld, J.: Hydroxy radical buffered by isoprene oxidation over tropical forests, Nature Geoscience, 5, 190-193, doi:10.1038/ngeo1405, 2012.

Tuazon, E. C. and Atkinson, R.: A product study of the gas-phase reaction of isoprene with the $\mathrm{OH}$ radical in the prescence of NOx, Int. J. Chem. Kinet., 22, 1221-1236, doi:10.1002/kin.550221202, 1990.

Wolfe, G. M., Thornton, J. A., Bouvier-Brown, N. C., Goldstein, A. H., Park, J.-H., McKay, M., Matross, D. M., Mao, J., Brune, W. H., LaFranchi, B. W., Browne, E. C., Min, K.-E., Wooldridge, P. J., Cohen, R. C., Crounse, J. D., Faloona, I. C., Gilman, J. B., Kuster, W. C., de Gouw, J. A., Huisman, A., and Keutsch, F. N.: The Chemistry of Atmosphere-Forest Exchange (CAFE) Model - Part 2: Application to BEARPEX-2007 observations, Atmos. Chem. Phys., 11, 1269-1294, doi:10.5194/acp-11-12692011, 2011.
Wooldridge, P. J., Perring, A. E., Bertram, T. H., Flocke, F. M., Roberts, J. M., Singh, H. B., Huey, L. G., Thornton, J. A., Wolfe, G. M., Murphy, J. G., Fry, J. L., Rollins, A. W., LaFranchi, B. W., and Cohen, R. C.: Total Peroxy Nitrates ( $\Sigma$ PNs) in the atmosphere: the Thermal Dissociation-Laser Induced Fluorescence (TD-LIF) technique and comparisons to speciated PAN measurements, Atmos. Meas. Tech., 3, 593-607, doi:10.5194/amt-3-5932010, 2010.

Wu, S. L., Mickley, L. J., Jacob, D. J., Logan, J. A., Yantosca, R. M., and Rind, D.: Why are there large differences between models in global budgets of tropospheric ozone?, J. Geophys. Res.-Atmos., 112, D05302, doi:10.1029/2006JD007801, 2007. 